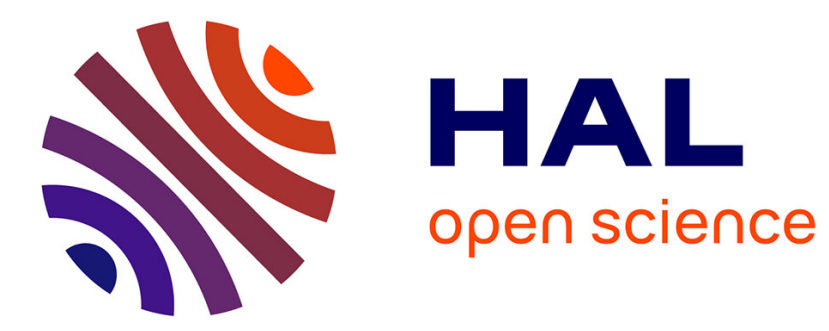

\title{
Microwave-assisted solid-phase synthesis of hydantoin derivatives
}

\author{
Evelina Colacino, Frédéric Lamaty, Jean Martinez, Isabelle Parrot
}

\section{To cite this version:}

Evelina Colacino, Frédéric Lamaty, Jean Martinez, Isabelle Parrot. Microwave-assisted solidphase synthesis of hydantoin derivatives. Tetrahedron Letters, 2007, 48 (30), pp.5317-5320. 10.1016/j.tetlet.2007.05.084 . hal-00204482

\section{HAL Id: hal-00204482 \\ https://hal.science/hal-00204482}

Submitted on 2 Feb 2021

HAL is a multi-disciplinary open access archive for the deposit and dissemination of scientific research documents, whether they are published or not. The documents may come from teaching and research institutions in France or abroad, or from public or private research centers.
L'archive ouverte pluridisciplinaire $\mathbf{H A L}$, est destinée au dépôt et à la diffusion de documents scientifiques de niveau recherche, publiés ou non, émanant des établissements d'enseignement et de recherche français ou étrangers, des laboratoires publics ou privés. 


\title{
Microwave-assisted solid-phase synthesis of hydantoin derivatives
}

\author{
Evelina Colacino, Frédéric Lamaty, Jean Martinez and Isabelle Parrot* \\ Institut des Biomolécules Max Mousseron, UMR 5247 CNRS-Universités Montpellier 1 et 2, Pl. Eugène, Bataillon, \\ 34095 Montpellier Cedex 5, France
}

\begin{abstract}
A microwave-assisted synthesis of 3,5- and 1,3,5-substituted hydantoins starting from various resins for solid-phase combinatorial chemistry has been developed. The hydantoins were synthesized from pre-loaded resins with amino acids via treatment with isocyanate or phenylisocyanate and subsequent intramolecular cyclization. Both reactions were performed under microwave irradiation. We studied the cyclative cleavage leading to hydantoin compounds dependent on the nature of the amino acid and the nucleofuge properties of the resin.
\end{abstract}

Hydantoin moiety constitutes an attractive pharmacological scaffold present in several drugs. ${ }^{1}$ This small and rigid heterocyclic backbone, presenting three points of diversity, could act on various pharmacological targets. Especially, hydantoin nucleus could be found in a broad range of biological active compounds displaying neuroprotective, antiarrhythmic, anticonvulsant, antihypertensive, anti-inflammatory, analgesic, antidiabetic, antiandrogen, antibacterial, antiviral, antifungal, or diuretic activities as well as herbicidal or fungicidal properties. ${ }^{2-10}$ Various alkaloid compounds from marine organisms or bacteria contain also an hydantoin moiety. ${ }^{1}$ Moreover, hydantoins are the key intermediates during the synthesis of optically pure natural and unnatural amino acids especially those involved on metabotropic ligands. ${ }^{11-13}$

In order to quickly generate large libraries of hydantoins, we expected that the combination of the solid-phase tool and the microwave technology will be useful for the development of efficient methodologies for the production of hydantoin scaffolds for drug discovery. Microwave irradiation technology in organic synthesis has now become an integrated part of combinatorial chemistry and drug discovery process. ${ }^{14-19}$ Microwave irradiation heats the reaction contents directly by taking advantage of the ability of some liquids and solids to

Keywords: Hydantoin; Solid-phase synthesis; Microwave irradiation; Cyclative cleavage.

* Corresponding author. Tel.: +33 (0) 4 67144986; fax: +33 (0) 4 67144866; e-mail: isabelle.parrot@univ-montp2.fr transform electromagnetic radiation into heat. The short reaction times and expanded reaction range offered by microwave-assisted chemistry in conjunction with the well-known advantages of solid-phase chemistry could allow us to generate hydantoin leads efficiently. Although several synthetic methods are described for the preparation of hydantoin libraries, including microwave-assisted liquid-phase combinatorial synthesis, none of them combines solid-phase and microwave synthesis, to the best of our knowledge..$^{1,20,21}$ The novel part of this paper is the use of microwave energy/heating, but combined with solid-phase technology this would have to be the most efficient route in terms of reaction time taken, product purity, and yield that can be achieved.

Since the first report of solid-phase synthesis of hydantoin libraries by DeWitt et al., ${ }^{22}$ several synthetic methods have been developed on resins or PEG. ${ }^{23-27}$ We were especially interested by base-catalyzed cyclative cleavage strategies allowing both cyclization and cleavage in one step. ${ }^{28}$ The hydantoin formation via solid-phase intramolecular cyclization is well represented in the literature. The major advantage of this strategy resides in the fact that products which are not capable of cyclization remain attached to the solid support leading

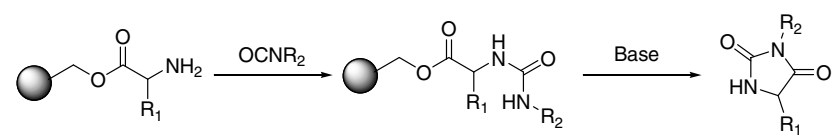

Scheme 1. 
generally to highly pure compounds. The rate of cyclization is then dependent on the nature of the side chains $\mathrm{R}_{1}$ and $\mathrm{R}_{2}$ attached to the cyclic compound in formation, but also dependent on the nucleofuge property of the resin under the same basic conditions (Scheme 1).
For the synthesis of hydantoin libraries on solid support, one of the most powerful methods could be the use of commercially available pre-loaded resins with $\mathrm{N}$-protected amino acids. Suitable N-deprotection of the amino acid followed by reaction of the resin with

Table 1. Hydantoins produced via Scheme 2

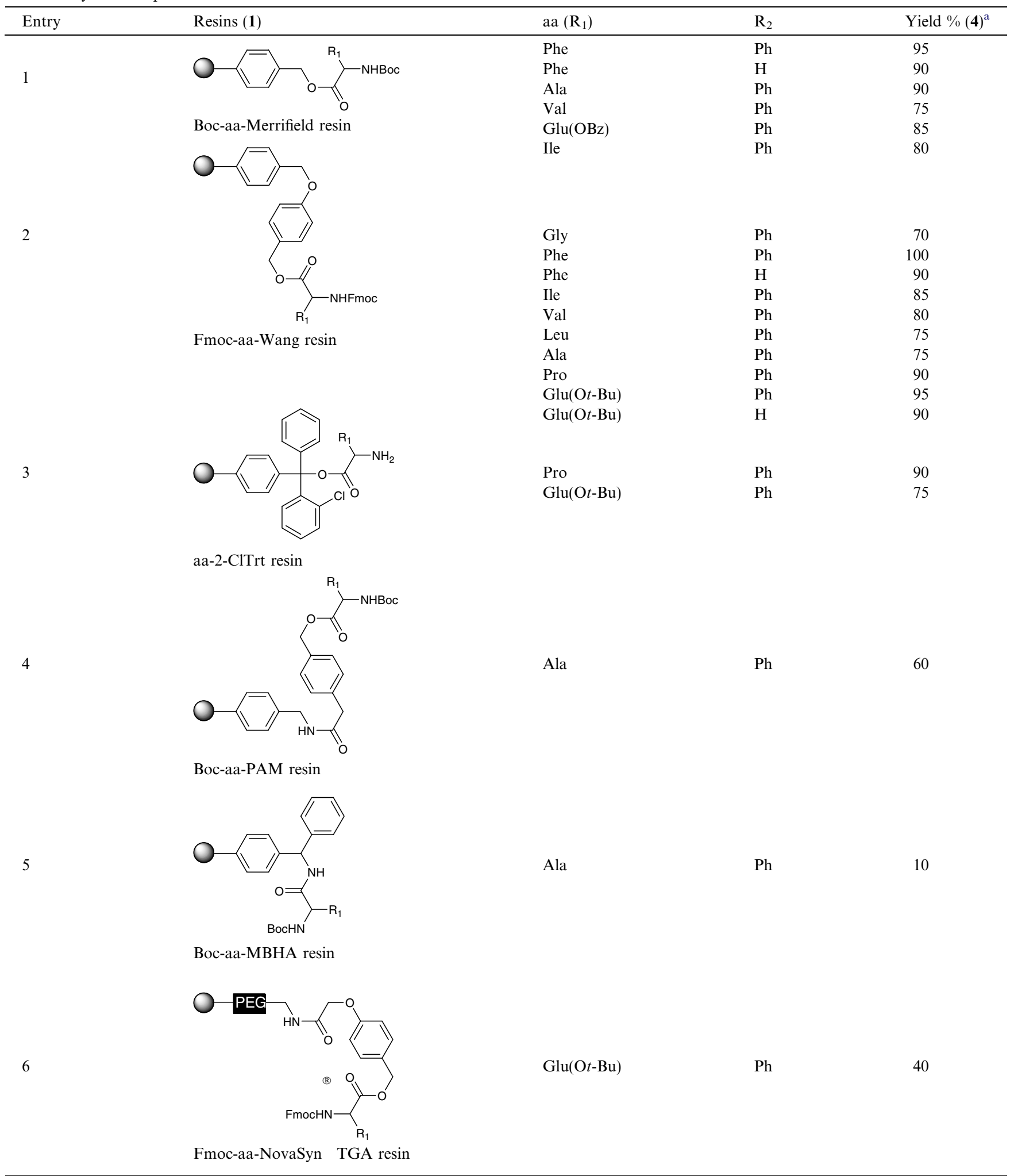

\footnotetext{
${ }^{a}$ Yields determined by weighing of crude sample (95-100\% purity determined by HPLC analysis).
} 


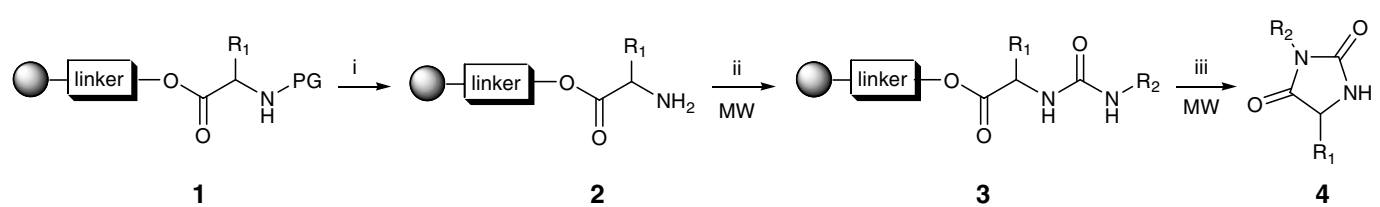

Scheme 2. Reagents and conditions: (i) $20 \%$ piperidine in DCM, 20 min, rt or 50\% TFA in DCM, $1 \mathrm{~h}, \mathrm{rt}, \mathrm{then}_{3} \mathrm{~N}$, (ii) $\mathrm{R}_{2} \mathrm{NCO}, \mathrm{THF}, \mathrm{MW}$ irradiation power $300 \mathrm{~W}, 10 \mathrm{~min}$; and (iii) $\mathrm{Et}_{3} \mathrm{~N}$, THF/DMF (4:1 v/v), MW irradiation power $300 \mathrm{~W}, 15 \mathrm{~min}$.

an isocyanate could generate the corresponding urea (Scheme 1). Treatment of this intermediate with a base leads to nucleophilic attack on the ester (or amide) allowing the release of the hydantoin product. Under these basic conditions, urea will undergo cleavage, while unreacted amino acid will remain on the support. $^{21,23,24,26,27,29-32}$ After cleavage, only the desired product is released in the solution, therefore facilitating significantly the purification step.

In order to determine the most suitable resin for such transformation under microwave heating, we studied and compared the performance of various resins under the same microwave conditions. For this purpose, reactions were performed using various combinations of resins, spacers, linkers, or amino acids (Table 1). The general synthetic route toward the targeted molecules is shown in Scheme 2. After N-deprotection of the anchored amino acid (Boc or Fmoc protecting group, except in the case of aa-2-ClTrt resin, entry 3) at room temperature, the two other steps were carried out under microwave conditions using a single mode cavity synthesizer to ensure reproducibility. At each step, the reaction conditions were optimized under microwave irradiation using various experimental conditions such as temperature, reaction time, power of the irradiation, solvent, and concentration of starting materials. The reaction progress was monitored by IR of the resin (urea FTIR at $1656 \mathrm{~cm}^{-1}$ ) and by LC/MS and ${ }^{1} \mathrm{H}$ NMR analyses of the final hydantoin. The treatment of the free amine moiety of the solid-phase bound amino acid $(1.0 \mathrm{~g}$, $0.76 \mathrm{mmol}, 0.76 \mathrm{mmol} / \mathrm{g})$ with isocyanate $(3.04 \mathrm{mmol})$ was achieved in THF $(5 \mathrm{~mL})$ in a microwave reactor at $60{ }^{\circ} \mathrm{C}$ for $10 \mathrm{~min}$. A control reaction for isocyanate coupling was performed in parallel, at room temperature in THF, for $10 \mathrm{~h}$ to achieve the same completion. The resin was then washed, dried and treated with $\mathrm{Et}_{3} \mathrm{~N}(0.43 \mathrm{~mL}, 3.04 \mathrm{mmol})$ in THF/DMF $(5 \mathrm{~mL}, 4: 1$ $\mathrm{v} / \mathrm{v}$ ) in a microwave reactor at $110^{\circ} \mathrm{C}$ for $15 \mathrm{~min}$. Higher temperatures did not give any additional improvements. A control reaction for cyclative cleavage was also performed under normal thermal heating in refluxing THF for $12 \mathrm{~h}$ to achieve the same completion. Under optimal conditions, hydantoins were obtained from 2 in $25 \mathrm{~min}$ instead of $22 \mathrm{~h}$ under conventional wellknown conditions.

This general protocol ${ }^{33}$ could be applied to all the previously described pre-loaded resin with an ester linkage between the amino acid and the resin (Table 1, entries $1-4)$ allowing the synthesis of a library of various hydantoins with good to excellent yields. We were able to provide for a diverse set of amino acids, heterocyclic compounds with yields in the same order to conven- tional solid-phase synthesis. All the tested resins were found to resist under microwave irradiation. However, the amide bound resins, less sensitive to cleavage due to their poor nucleofuge potential, released hydantoin compounds with lower yields (Table 1 , entries 5 and 6). We reasoned that an ester linkage is more suitable for cyclative cleavage, following our general basic protocol under microwave irradiation.

The results from the solid-phase synthesis of hydantoins by cyclorelease strategy clearly demonstrate that microwave irradiation offers an effective and attractive technique to produce a library of hydantoins with short reaction times, in high yields, and with high purity compared to conventional classic thermal described in the literature. Microwave-assisted heating should prove highly practical for combinatorial solid-phase synthesis of hydantoins or other heterocyclic scaffolds.

\section{Acknowledgements}

We thank the CNRS and the 'Ligue Contre le Cancer' for financial support.

\section{References and notes}

1. Meusel, M.; Gutschow, M. Org. Prep. Proced. Int. 2004, 36, 391-443.

2. Brouillette, W. J.; Jestkov, V. P.; Brown, M. L.; Akhtar, M. S.; Delorey, T. M.; Brown, G. B. J. Med. Chem. 1994, 37, 3289-3293.

3. Matsugi, T.; Kageyama, M.; Nishimura, K.; Giles, H.; Shirasawa, E. Eur. J. Pharmacol. 1995, 275, 245-250.

4. Osz, E.; Somsak, L.; Szilagyi, L.; Kovacs, L.; Docsa, T.; Toth, B.; Gergely, P. Bioorg. Med. Chem. Lett. 1999, 9, 1385-1390.

5. Schelkun, R. M.; Yuen, P. W.; Serpa, K.; Meltzer, L. T.; Wise, L. D.; Whittemore, E. R.; Woodward, R. M. J. Med. Chem. 2000, 43, 1892-1897.

6. Scicinski, J. J.; Barker, R. D.; Murray, P. J.; Jarvie, E. M. Bioorg. Med. Chem. Lett. 1998, 8, 3609-3614.

7. Stilz, H. U.; Guba, W.; Jablonka, B.; Just, M.; Klingler, O.; Konig, W.; Wehner, V.; Zoller, G. J. Med. Chem. 2001, 44, 1158-1176.

8. Kuang, R. Z.; Epp, J. B.; Ruan, S. M.; Yu, H. Y.; Huang, P.; He, S.; Tu, J.; Schechter, N. M.; Turbov, J.; Froelich, C. J.; Groutas, W. C. J. Am. Chem. Soc. 1999, 121, 81288129.

9. Kuang, R. Z.; Epp, J. B.; Ruan, S.; Chong, L. S.; Venkataraman, R.; Tu, J.; He, S.; Truong, T. M.; Groutas, W. C. Biorg. Med. Chem. 2000, 8, 1005-1016.

10. Ohta, H.; Jikihara, T.; Wakabayashi, K.; Fujita, T. Pestic. Biochem. Phys. 1980, 14, 153-160. 
11. Monn, J. A.; Valli, M. J.; Massey, S. M.; Wright, R. A.; Salhoff, C. R.; Johnson, B. G.; Howe, T.; Alt, C. A.; Rhodes, G. A.; Robey, R. L.; Griffey, K. R.; Tizzano, J. P.; Kallman, M. J.; Helton, D. R.; Schoepp, D. D. J. Med. Chem. 1997, 40, 528-537.

12. Monn, J. A.; Valli, M. J.; Massey, S. M.; Hansen, M. M.; Kress, T. J.; Wepsiec, J. P.; Harkness, A. R.; Grutsch, J. L.; Wright, R. A.; Johnson, B. G.; Andis, S. L.; Kingston, A.; Tomlinson, R.; Lewis, R.; Griffey, K. R.; Tizzano, J. P.; Schoepp, D. D. J. Med. Chem. 1999, 42, 1027-1040.

13. Tellier, F.; Acher, F.; Brabet, I.; Pin, J. P.; Azerad, R. Biorg. Med. Chem. 1998, 6, 195-208.

14. Lidstrom, P.; Tierney, J.; Wathey, B.; Westman, J. Tetrahedron 2001, 57, 9225-9283.

15. Hayes, B. L.; Collins, M. J. Abstr. Paper Am. Chem. Soc. 2004, 227, U207.

16. Larhed, M.; Hallberg, A. Drug Discovery Today 2001, 6, 406-416.

17. Majetich, G.; Hicks, R. J. Microw. Power Electromagn. Energy 1995, 30, 27-45.

18. Majetich, G.; Hicks, R. Radiat. Phys. Chem. 1995, 45, $567-579$.

19. Loupy, A. Microwaves in Organic Synthesis; Wiley-VCH: Weinheim, 2002.

20. Faghihi, K.; Zamani, K.; Mobinikhaledi, A. Turk. J. Chem. 2004, 28, 345-350.

21. Lee, M. J.; Sun, C. M. Tetrahedron Lett. 2004, 45, 437440.

22. Dewitt, S. H.; Kiely, J. S.; Stankovic, C. J.; Schroeder, M. C.; Cody, D. M. R.; Pavia, M. R. Proc. Natl. Acad. Sci. U.S.A. 1993, 90, 6909-6913.

23. Kim, S. W.; Ahn, S. Y.; Koh, J. S.; Lee, J. H.; Ro, S.; Cho, H. Y. Tetrahedron Lett. 1997, 38, 4603-4606.

24. Hanessian, S.; Yang, R.-Y. Tetrahedron Lett. 1996, 37, 5835-5838.
25. Stadlwieser, J.; Ellmerer-Muller, E. P.; Tako, A.; Maslouh, N.; Bannwarth, W. Angew. Chem., Int. Ed. 1998, 37, 1402-1404.

26. Boeijen, A.; Kruijtzer, J. A. W.; Liskamp, R. M. J. Bioorg. Med. Chem. Lett. 1998, 8, 2375-2380.

27. Park, K.-H.; Kurth, M. J. Tetrahedron Lett. 2000, 41, 7409-7413.

28. James, I. W. Tetrahedron 1999, 55, 4855-4946.

29. Albericio, F.; Garcia, J.; Michelotti, E. L.; Nicolas, E.; Tice, C. M. Tetrahedron Lett. 2000, 41, 3161-3163.

30. Wu, S. D.; Janusz, J. M. Tetrahedron Lett. 2000, 41, 1165 1169.

31. Lamothe, M.; Lannuzel, M.; Perez, M. J. Comb. Chem. 2002, 4, 73-78.

32. Dressman, B. A.; Spangle, L. A.; Kaldor, S. W. Tetrahedron Lett. 1996, 37, 937-940.

33. General procedure for the synthesis of hydantoins. All the microwave-assisted reactions were performed at $300 \mathrm{~W}$ in a $20 \mathrm{~mL}$ vial with a Biotage Initiator $60 \mathrm{EXP}^{\circledR}$. Temperature was measured with an IR sensor on the outer surface of the reaction vial.

After suitable conventional $\mathrm{N}$-deprotection of the preloaded resin 1, the resulting DCM-swollen resin 2 (1.0 g, $0.76 \mathrm{mmol}, 0.76 \mathrm{mmol} / \mathrm{g})$ was treated with isocyanate $(3.04 \mathrm{mmol})$ in THF $(5 \mathrm{~mL})$ in a microwave reactor at $60{ }^{\circ} \mathrm{C}$ for $10 \mathrm{~min}$. The solvent was removed by filtration and the resin was washed with THF $(2 \times 10 \mathrm{~mL}), \mathrm{DMF}$ $(2 \times 10 \mathrm{~mL}), \mathrm{MeOH}(2 \times 10 \mathrm{~mL}), \mathrm{DCM}(2 \times 10 \mathrm{~mL})$, and dried. This resin 3 was then treated with $\mathrm{Et}_{3} \mathrm{~N}(0.43 \mathrm{~mL}$, $3.04 \mathrm{mmol})$ in THF/DMF $(5 \mathrm{~mL}, 4: 1 \mathrm{v} / \mathrm{v})$ in a microwave reactor at $110{ }^{\circ} \mathrm{C}$ for $15 \mathrm{~min}$. The solvent was removed by filtration and the resin was washed with THF $(2 \times 10 \mathrm{~mL})$ and DCM $(2 \times 10 \mathrm{~mL})$. Combined filtrates were dried to obtain the desired product 4 in a crude yield calculated on the basis of the initial loading support. 